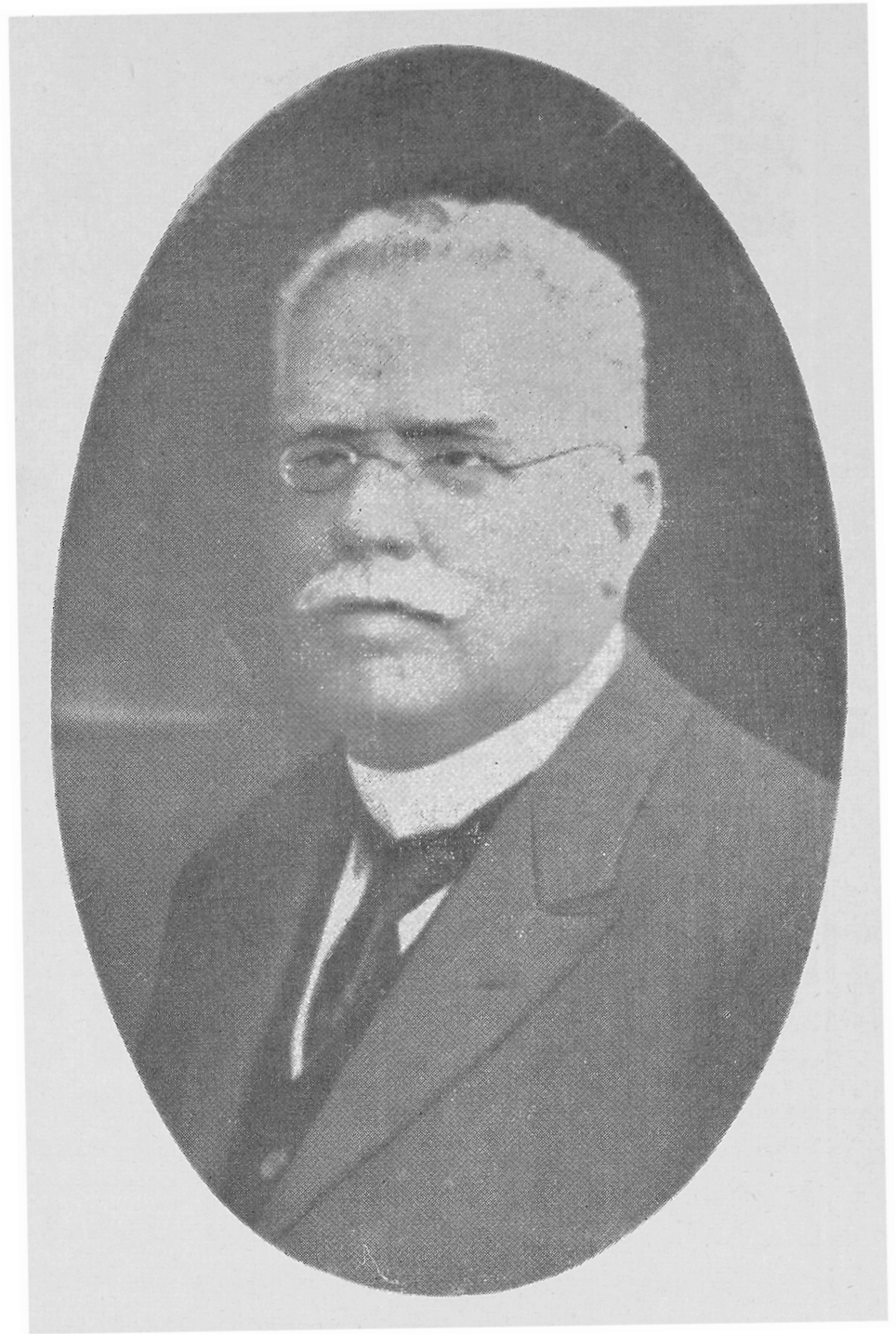

Pedro Augusto Carneiro Lessa 


\section{Pedro Augusto Carneiro Lessa}

(1859-1921)

Comemora o Brasil, êste ano, o centenário do nascimento de dois jurisconsultos dos mais eminentes da intelectualidade pátria: Clovis Bevilaqua e Pedro Lessa.

Para a Faculdade de Direito de São Paulo a efeméride possui particular significação, pois é Clovis um de seus dois professôres eméritos, sendo Pedro Lessa considerado, com justiça, o verdadeiro instituidor dos estudos filosóficojurídicos em São Paulo.

Em comemoração dos dois mestres da cultura e da jurisprudência nacionais, tendo por sede a Faculdade de Direito, reuniu-se, com assinalado brilho, de 9 a 14 de novembro, o III CONGRESSO NAGIONAL DE FILOSOFIA, convocado pelo Instituto Brasileiro de Filosofia, sendo as sessões plenárias do certame dedicadas especialmente ao estudo da obra daqueles dois grandes mestres do pensamento jurídico-filosófico brasileiro. A Congregação dos professôrẹs deu integral apoio ao certame, deliberando fôsse editado um volume especial desta Revista em homenagem ao seu antigo catedrático de Filosofia do Direito.

Nasceu Pedro Lessa na cidade do Serro, na então província de Minas Gerais, aos 25 de setembro de 1859. Filho de José Pedro Lessa e de D. Francisca Amélia da Fonseca Carneiro Lessa.

Feitos os preparatórios, veio matricular-se na Faculdade de Direito de São Paulo, em 1879. Bacharelou-se em 30 de outubro de 1883, após haver participado intensamente da vida acadêmica, revelando suas convicções republicanas e seu entusiasmo pelas novas correntes do pensa- 
mento filosófico, como um dos colaboradores principais de "A República" e "A Luta".

Onze dias após a formatura, a 10 de novembro, inscreveu-se para a defesa de teses e foi aprovado, recebendo, em 1884, o grau de doutor em direito.

Foi, em seguida, nomeado secretário da Relação de São Paulo e presidente da província do Maranhão.

Nomeado lente substituto, por decreto de 30 de maio de 1888, tomou posse a 6 de junho. Promovido a lente catedrático da primeira cadeira da primeira série, por decreto de 21 de março de 1891, tomou posse a 13 de abril.

Nesse mesmo ano, por decreto de 6 de março, foì nomeado chefe da polícia de São Paulo, e, em junho, eleito deputado estadual.

Por decreto de 7 de fevereiro de 1892, foi designado catedrático de Filosofia do Direito e História do Direito, exercendo a cátedra com invulgar proficiência durante três lustros. Integrado na Filosofia positiva, não foi, no entanto, um positivista ortodoxo. Ao contrário, sua inteligência, sempre afeita a novos estímulos, recebeu as influências de várias fontes do pensamento da época, como Spencer, Littré e Stuart Mill. Como cultor da Filosofia do Direito, soube realizar a necessária harmonia entre as concepções gerais do Direito e a orientação positiva que vinha sendo dada às diversas disciplinas. Mestre respeitado como verdadeiro guia pelos moços, soube manter o pensamento das Arcadas a par das mais vivas correntes ideológicas do seu tempo.

Nomeado, na presidência Afonso Pena, por decreto de 26 de outubro de 1907, ministro do Supremo Tribunal Federal, traçou na magistratura, o perfil do maior dos juízes brasileiros. É com justiça lembrada a sua autação decisiva na fixação de princípios básicos do Direito Constitucional do novo regime. 
Ocupou, na Suprema Côrte, a cadeira que foi de Lúcio de Mendonça, a quem também sucedeu na Academia Brasileira de Letras.

Fundou e presidiu a Liga de Defesa Nacional, o que demonstra jamais se ter divorciado dos problemas fundamentais da nacionalidade.

Faleceu aos 25 de julho de 1921.

Sôbre o significado de sua atuação na cátedra e no Supremo Tribunal Federal, assim como sôbre o papel por êle desempenhado na história do Direito Constitucional brasileiro, publica esta Revista três estudos que fixam com precisão a sua alta personalidade.

Entre as homenagens especiais prestadas a Pedro Lessa, cabe aqui assinalar a memorável sessão promovida na Capital da República, pelo Instituto dos Advogados Brasileiros, sob a presidência do eminente Ministro Orozimbo Nonato, presidente do Supremo Tribunal Federal.

Dela participaram, como representantes desta Faculdade, o seu Diretor, Professor Luís Antônio da Gama e Silva, e os Professôres Ministro Cândido Motta Filho e Miguel Reale, a quem coube focalizar, com admirável acuidade e eloqüência, o significado de Pedro Lessa na história das idéias no Brasil.

\section{Bibliografia fundamental de Pedro Lessa:}

- É a historia uma ciência? Duprat \& Cia., São Paulo, 1900.

- Dissertações e Polêmicas, Rio de Janeiro, 1909.

- Estudos de Filosofia do Direito, 1912. Segundo edição da Livraria Francisco Alves, em 1916.

- O determinismo psíquico e a imputabilidade e responsabilidade criminal. São Paulo, 1915.

- Do Poder Judiciário. Livraria Francisco Alves. Rio de Janeiro.

- Discursos e Conferências, 1916. 